is very small in proportion to total oil requirements, there is, as the Committee points out, no reason why home-produced oil should not play its due part in the new developments, provided the manufacturer is free to use, unaffected by duties or their repercussions, the material most suitable for his purpose.

It is, of course, to this section of the report that Sir Frank Smith's lectures are most relevant, and the importance of the matter is well shown by some of the figures quoted by Sir Frank Smith. To-day, he said, some two hundred chemicals are made on the commercial scale from petroloum raw materials, the annual value of which he estimated at about $£ 200$ millions, and in the plastics industry the ratio of petroloum derivatives to non-petroleum derivatives as raw materials is steadily increasing. By cracking processes there are already produced 60,000 tons of ethylene for the plastics industry and 120,000 tons for ethyl alcohol. The actual volume of refinery gases in the world is about 300,000 million eubic feet per annum or 15 million tons, and acetylene is already being made from petroleum and production may be on a very large scale in the future.

Sir Frank Smith contended that there is no antagonism between the coal-chemical industry and a petroleum-chemical industry, and this contention is borne out by the third section of the Ayre Committee report, dealing with coal as a source of chemical raw materials. Surveying first the low-temperature and high-temperature carbonization processes, the Committee concludes that the producer of indigenous hydrocarbons cannot and should not be called upon to bear the cost of reduction in price of his products to the chemical industry, notwithstanding that the protection affordod in 1938 to encourage the production from indigenous materials of fuels for the internal combustion engine had raised the price of certain raw materials to the chemical industry. Considering next the three chief processes for treating coal which yield raw materials for the organic chemical industry-hydrogenation, the Fischer Tropsch process for hydrocarbon synthesis (which has not yet been operated in Britain), and the production of calcium carbide-the Committee finds it difficult to forecast the part which these processes will play in the development of the chemical industry, but believes that it will not be large in the immediate future, and that its recommendations will not impede their development.

The Committee recommends accordingly that chemical manufacturers be allowed to receive without payment of duty (or upon drawback), as raw material for chemical synthesis, any imported hydrocarbon oil, and the Chancellor of the Exchequer, as already noted, indicated his intention of amending appropriately Section 2 of the Finance Act, 1934. In respect of hydrocarbon oils produced from indigenous material and received by a chemical manufacturer as raw material for chemical synthesis, the Committee recommends payment to the manufacturer of an allowance equal to the duty payable on the importation of like oils. Similarly, any producer or refiner of indigenous oils who uses such oils for the production of hydrocarbons for use in the refinery as raw materials in chemical synthesis should also receive an allowance equal to the duty payable in the importation of like oils. On the basis of the pre-war consumption of indigenous hydrocarbon oils by the chemical industry, the total cost of implementing the Committee's recommendations is estimated at somothing less than $£ 400,000$ a year.
In announcing his acceptance of these recommendations, the Chancellor said that many believe that synthetic chemical processes will be of rapidly growing importance in manufacture, and will affect industries outside the field of synthetic chemistry. Research on these problems has been active in several countries during the last five years, and he said he hoped that the gift he was able to make towards the cost of research by this concession will help Britain to establish itself quickly in a worthy position in relation to these new developments. While the Ayre Report does not cover the whole field-and it may well be desirable to examine the wider question of home refining in relation to national economic policy - when read with the Cantor Lectures of Sir Frank Smith, it shows conclusively that we can no longer be content to treat oil questions only as matters of Imperial defence. Equally it endorses the argument of the Parliamentary and Scientific Committee for an adequate examination of our whole policy of the utilization of our coal resources. The prompt acceptance of the Committee's recommendations is a further indication of official recognition of the importance of scientific and industrial research, and a disposition to accord scientific and technical factors their due weight in the determination of policy.

\section{RUSSIAN PHYSICS JOURNALS}

$\mathrm{F}^{\circ}$ R a time, when transport between the U.S.S.R. and Great Britain was very difficult, the flow of scientific journals almost stopped. Recently a fairly regular exchange has been re-established. The following notes on physies journals may help those readers to whom the facilities of the London libraries are not readily accessible, but who nevertheless wish to know how physies has fared in the U.S.S.R. in recent years. On first thoughts, a knowledge of the Russian language may seem essential; but realizing the severe difficulties of their language the Russians for more than ten years have been publishing foreign editions, in German, French or English, of some of their journals. Attention will be confined almost entirely to such journals.

The earliest journal of special interest to physicists appears to be the Physikalische Zeitschrift der Sowjetunion, published at the rate of two volumes each year starting in 1932. Although most of the papers are in German, some papers are in English. Next to be started was Technical Physics of the U.S.S.R., founded in 1934, having papers in English, German or French. By 1939 the fifth volume had been reached with a publication.rate of about twelve parts a year. The centre of publication was Leningrad. In the first volume the editor, A. Joffe, explains that before the Revolution there was practically no technical physics in Russia. By 1934 a number of institutes giving their attention to immediate problems in technical physics had been established. Joffe lists them in seven groups: (1) a group of physical-technical institutes including four Leningrad institutes, Kharkov, Ural, Siberia, Dniepropetrovsk and the Physical Agronomical Institute with one thousand workers; (2) the Optical Institute - with four hundred workers ; (3) the AllUnion Electro-Technical Institute with one thousand workers; (4), the Power and Thermal Institutes; (5) the Central Radio Laboratory ; (6) the Metallurg- 
ical Institutes; and (7) the Institute of Applied Mineralogy and others. At that time there were about three hundred technical scientific publications in Russian. The scope of the journal can be seen from the editor's list comprising (1) electron physies, dielectrics, high-voltage technique, high-frequency physics and gaseous discharge, (2) mechanical testing of materials and structure analysis, (3) thermal technology, (4) applied optics, including illumination, photography and electro-physics, (5) technical acoustics, and (6) high-vacuum physics. Scientific workers of all countries are invited to contribute papers and the editor concludes: "We hope that our journal will help to eliminate the language difficulty which prevents foreigners from becoming acquainted with our work and will form yet another link in the chain drawing science and scientists of all countries together". Under the heading 'Bibliography', detailed summaries in English are sometimes given of papers appearing in Russian in other Russian journals.

In 1939 , on the basis of the experience gained in publishing these two journals, the Physical and Mathematical Department of the Academy of Sciences decided to replace them by a single journal, the Journal of Physics, published from Moscow with S. I. Vavilov as editor. The papers were to be in English, French and German and to include all branches of physies whether theoretical, experimental or technical. The cover bears the portrait of the first Russian physicist, M. V. Lomonosov (1711-65), who was also the first to combine scientific research work with the solution of practical and economic problems. Outside contributions are invited. "We gladly offer the pages of our journal to foreign scientists who would be willing to publish their works through the medium of the Journal of Physics." Parts are issued monthly at the rate of two volumes each year. Fittingly the first two papers to appear are by Prof. P. Kapitza on an "Expansion Turbine Producing Low Temperatures Applied to Air Liquefaction" and "Influence of Frictional Forces on the Stability of High-Speed Rotors". The other two papers completing the first part are by A. Filippov and co-workers on "Disintegration of Atomic Nuclei of Cosmic Rays" and "Fluorescence of Aqueous Solutions of Rare Earth Salts". The last two parts of the first volume were issued together, dealing chiefly with work of L. I. Mandelstam and his collaborators and pupils, with a special article in celebration of his sixtieth anniversary. A language analysis of the first volume shows forty papers in English and five in French. The second volume has thirty-six papers in English, two in French and three in German.

At one time statements were made giving the impression that Russian physicists had to devote the whole of their attention to subjects of immediate practical use. There is no justification to be found in this journal for such statements of short-sighted policy. For example, in the analytical index to volume 4, it was necessary to provide entries |for the following subjects representative of all the main branches of physics: acoustics, cosmic radiation, crystalline state, dielectries, discharge of electricity in gases, electrical conductivity, electrolytes, electromagnetic theory, electronics, Hall effect, ionization, ionosphere, liquids, luminescence, low temperatures, magnetic properties, quantum mechanies, methods, machines and instruments, nuclear structure, optical constants and properties, optical theory, photoelectric effect, radiation, radio, scattering of light, scattering of particles, spectra (molecular), super- conductive state, thermal conductivity, vibration theory. From volume 6 onwards, the editor has been P. L. Kapitza, with E. V. Schpolsky as vice-editor. In volume 5 a new feature was started in giving a list of contents of Russian physics journals, including the titles in Russian and English, but "only those articles whose translations are not published in the Journal of Physics". All bibliographical details of the original Russian journals from which the full translations are made are unfortunately omitted. In format, style and content, the Journal, which is now being received regularly in Great Britain, is very similar to the Physical Review. The majority of papers are in English, with a few in French or German.

The remaining physics journals are published entirely in Russian. Recently the practice of giving also a title index and summary in some other European language has unfortunately stopped. Copies are, however, being received in Britain of several other journals of special interest to physicists. Acta Physiochimica U.R.S.S. is similar in content to the Transactions of the Faraday Society, and is published almost entirely in English. with occasionally a paper in French. Each volume consists of six issues and by 1944 the nineteenth volume had been reached. The chief editor is Prof. A. Frumkin, Bolshaya Kalwzhskaya 31, Institute of Colloid- and Electrochemistry, Academy of Sciences of the U.S.S.R., Moscow. Although the Comptes Rendus (Doklady) de l'Académie des Sciences de l'URSS. covers all the sciences, almost every issue contains work by physicists. The journal is published about once in ten days. Articles are seldom longer than three or four pages, and they deal in either English or French with the very latest results of work in progress or just completed. The editorial address is Kazan, rue Baumann, 19. To science students of the Russian language this journal is of special interest, as it is a direct translation of the Russian edition. . Both editions are received by the Science Section of the S.C.R., 98 Gower Street, London, W.C.1. Although the Bulletin de l'Académie des Sciences de l'URSS., Série Physique is published in Russian, a short abstract in English of each paper is given in the earlier volumes. By 1943, this practice had stopped, presumably owing to war difficulties.

The most complete sets of journals are to be found in the national libraries of the Patent Office, the British Museum and the Science Museum, and in tre private library of the Royal Society. The British Museum has a list, which can be seen in the Reading Room, of scientific and technical periodicals received from the U.S.S.R. during 1933-42. A similar ASLIB list is out of print, but can be seen at 31 Museum Street, London, W.C.1. Perhaps the fullest abstracting service from Russian journals is that of the Chemical Abstracts of the United States. The fullest card-index of the present whereabouts of any particular number of a journal is that of ASLIB. This card-index is of great value to the research worker as it covers all the main libraries of the country. At present, no one library has a complete run of any current Russian journal. An index of each separate number is therefore essential, and the ASLIB index is kept up to date in step with the information supplied by the separate libraries.

A note may be added on transliteration. At least four different systems are in use in the London libraries, and even the Academy of Sciences has not yet reached uniformity, for Prof. Kapitza's name is spelt 
differently in two different journals. When the controversial symbols occur in the middle of a word no harm is done. A state of affairs in which an author's name may occur under $c$ in one index and $t$ in another is, however, very confusing. Research workers who do not read Russian would find it well worth the small effort needed to learn the Russian alphabet and system of transliteration for, in physics at least, many of the technical terms can be recognized as soon as they are transliterated even without the use of a dictionary. Mathematics, tables of results, graphs, diagrams and photographs can therefore be recognized from the captions, which usually involve little grammatical construction. A technical EnglishRussian dictionary is available (by A. E. Chernukhin, State Theo. Tech. Pub. House, Moscow, 1934), but no Russian-English technical dictionary has been published. There is at present no technical Russian grammar. The writer wishes to thank the authorities named for help in collecting the above data, and would be grateful to receive additional information or corrections of errors for which he is alone responsible.

W. H. George.

\section{POST-WAR UNIVERSITY PROBLEMS IN THE UNITED STATES}

$\mathrm{T}$ HE report of the president of Harvard to the Board of Overseers is always an important doeument. On this occasion ${ }^{1}$ it is perhaps more so than usual, because Dr. J. B. Conant reviews the part that ought to be played by universities in the demobilization period, and he gives an account of the Harvard proposals. British universities have been facing similar problems, and no doubt much can be gained by a consideration of what universities in the United States are proposing to do. There will always, of course, be some differences that originate from differences of outlook and position.

During the past year, Harvard has evolved the general outline of its programme, and though designed for the period of large-scale demobilization, it is equally applicable to the earlier intervening period when the number of 'veterans' is not likely to be large. Two considerations directed the planning. The first was to provide several opportunities each year for returning soldiers to enter the university without having to wait for the commencement of the next academic year; and the second was to shorten the total time necessary to complete the educational rehabilitation. Both of these are worthy considerations, though they should be regarded as essentially post-war measures and not ones that would normally be desirable under peace-time conditions. In order to achieve these ends the College and the Graduate School of Arts and Sciences will have two terms of sixteen weeks and one of twelve, and a returning soldier will be able to enter at the beginning of any one term.

Dr. Conant remarks that there is little or no enthusiasm for such a programme as a permanent basis, but he does express the opinion that it is an improvement on the old pre-war 32-34-woek twoterm academic year.

Harvard's present 48-week academic year has produced signs of strain in the student body, and no doubt similar strains have been evident in student bodies of British universities, especially during the last four years. It would appear that Dr. Conant considers that a $38-40$ week academic year is about the most suitable, because instruction is not too long nor too intensive, and there is time for reading (especially since a reading period of two weeks prior to the examinations is probably included). This con trasts with the Oxford and Cambridge year of about 24 weeks, where instruction has perforce to be intensive and the student lives in a whirl from the moment he comes up to the time he goes down. In other universities in Britain the academic year is somewhat longer and the pressure is probably not so great. The length of the academic year would seem to be a problem that should have some reconsideration in the light of present-day conditions of living.

Turning to problems of admission, Dr. Conant rightly issues a warning lest academic formalities and institutional rigidity drive away men with ambition and imagination. This is probably one of the greatest post-war problems facing the universities, and it will require all the tact and understanding of those who are called upon to deal with the exservicemen.

There are two other items in this report that merit attention. The first concerns the appointment to life positions on the various faculties. Naturally $a$ : university tries to secure the very best qualified men; but this is by no means easy as one may see from a study of the staff roll of any university. How far a proper solution has been found can be gauged by Dr. Conant's comment, "that nine times out of ten the normal forces working within any special segment of the University make for a good appointment, but against an excellent appointment. And it was President Lowell who said, "the surest way to ruin a University faculty is to fill it with good men'". This is an important truth which universities would do well to bear in mind, and it may be that new systems for making permanent appointments need to be evolved.

The second item, which should be heartily endorsed in Britain, is a suggestion that not too long after the War a comprehensive picture should be placed before the American public of the part played by the respective universities in the war effort, "For such a picture would go far towards fortifying the faith of the nation in its institutions of advanced learning". Britain has really only begun to appreciate the value of the universities during the War, and a justification of their immediate enlarged monetary demands could perhaps be better appreciated by the general public if some similar picture of their war effort were to be presented. Beautifully illustrated brochures have been produced showing what the Navy, Army and Air Foree have achioved during certain phases of the War. Could not a statement be issued showing the work of the universities? Here, however, a word of warning is necessary, and one cannot do better than conclude with Dr. Conant's own words : "if the story is told piecemeal and the approach is in a spirit of aggrandizement of a particular University and the claiming of a large measure of credit for this or that discovery or participation in this or that military operation, the public will soon sicken of the tale... the less glorification of the activities of the home front the better. What is said must be couched in terms of humility if it is to harmonize with the spirit of sacrifice and valour of those who bore the burden of actual combat".

V. J. Chapman. 